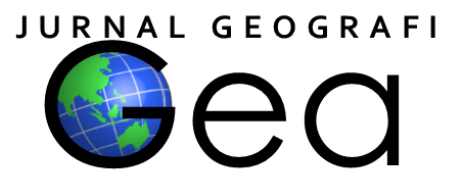

\title{
METODE DEFUZZIFIKASI ARTIFICIAL NEURAL NETWORK UNTUK KLASIFIKASI PENGGUNAAN LAHAN
}

\author{
Harvini Wulansari \\ Sekolah Tinggi Pertanahan Nasional \\ harvini@stpn.ac.id
}

\begin{abstract}
Artificial neural network is a non-parametric approach which does not require class statistical distribution to be described normally, the advantages of non-parametric approach are its ability to combine septral data and non-spectral data, which is assumed by adding non-spectral data, the resulting accuracy also increased. The method used in this study is a fuzzy logic-based approach with defuzzification using an artificial neural network algorithm. The input spectral data were taken from the ALOS AVNIR-2 image and non-spectral data in the form of slope, soil solum and image texture. This study resulted in an overall accuracy and kappa index that was not good or proper, however the results were still acceptable. The results of the overall accuracy calculation for the 14 land use classes of the artificial neural network defuzzification process involving spectral data only (4 bands ALOS AVNIR-2) were 55\% and the kappa index was 0.51. Meanwhile, when non-spectral data such as slope slope, soil solution and image texture are involved as input, the accuracy decreases in 14 land use classes, with an overall accuracy of $40 \%$ and a kappa index of 0.35 where the input slope and soil solum are interpolated in the software. ArcGIS first, while the one that was directly interpolated in the Idrisi Selva software, the overall accuracy was $49.75 \%$ and the kappa index was $0.45 \%$.
\end{abstract}

Keywords: land use classification, ALOS AVNIR-2 image, fuzzy logic, artificial neural network.

\begin{abstract}
ABSTRAK
Jaringan syaraf tiruan (artificial neural network) merupakan salah satu pendekatan non parametrik dimana tidak mengharuskan distribusi statistik kelas digambarkan secara normal, kelebihan dari pendekatan non parametrik kemampuannya dalam menggabungkan data sepktral dan data non spektral, yang diasumsikan dengan menambah data non spektral maka akurasi yang dihasilkan juga meningkat. Metode yang digunakan dalam penelitian ini yaitu metode pendekatan berbasis logika samar (fuzzy logic) dengan defuzzifikasi menggunakan algoritma artificial neural network. Input data spektral diambil dari Citra ALOS AVNIR-2 dan data non spektral berupa kemiringan lereng, solum tanah dan tekstur citra. Penelitian ini menghasilkan overall accuracy dan indeks kappa yang kurang baik atau kurang layak, namun demikian hasilnya masih dapat diterima. Hasil perhitungan overall accuracy untuk 14 kelas penggunaan lahan proses defuzzifikasi artificial neural network (jaringan syaraf tiruan) yang melibatkan data spektral saja (4 band ALOS AVNIR-2) sebesar 55\% dan indeks kappa 0,51. Sementara itu ketika data non spektral seperti kemiringan lereng, solum tanah dan tekstur citra dilibatkan sebagai input, akurasinya semakin menurun pada 14 kelas penggunaan lahan, dengan overall accuracy sebesar $40 \%$ dan indeks kappa 0,35 dimana input kemiringan lereng dan solum tanah diinterpolasi pada software ArcGIS
\end{abstract}


terlebih dahulu, sedangkan yang langsung diinterpolasi pada software Idrisi Selva overall accuracy sebesar $49,75 \%$ dan indeks kappa $0.45 \%$.

Kata kunci: klasifikasi penggunaan lahan, Citra ALOS AVNIR-2, logika samar, artificial neural network.

\section{PENDAHULUAN}

Teknologi penginderaan jauh merupakan salah satu alat yang dapat digunakan untuk melakukan analisis suatu area yang luas dan sulit dijangkau secara cepat, efisien, efektif dan lengkap. Saat ini teknologi penginderaan jauh sangat besar perannya dalam pengumpulan data geografis suatu wilayah, berbagai sektor sudah mulai menggunakan teknologi penginderaan jauh untuk memperoleh data spasial yang nantinya digunakan sebagai penentu kebijakan misal sektor pertanahan, sektor kehutanan, sektor pengembangan wilayah, sektor pertambangan dan lain-lain. Untuk dapat melakukan suatu analisis maka data penginderaan jauh perlu diolah agar dapat memberikan informasi yang mudah dipahami dan bermanfaat bagi pengguna. Beberapa penelitian mulai dikembangkan terkait pengolahan citra, salah satunya yaitu klasifikasi multispektral. Untuk pembuatan Peta Tematik, klasifikasi multisepktral atau klasifikasi digital bisa dijadikan alternatif sebagai masukan dalam pemodelan spasial karena dapat dilakukan dengan cepat dan murah. Permasalahannya adalah sebagai masukan data penginderaan jauh dengan cara klasifikasi multispektral untuk pembuatan Peta Tematik belum banyak dimanfaatkan oleh instansi yang ditugaskan untuk membuat Peta Tematik sehingga perlu diuji ketelitiannya. Dari permasalahan tersebut peneliti melakukan sebuah penelitian mengenai klasifikasi penggunaan lahan dengan metode defuzzifikasi artificial neural network. Tujuan dari penelitian adalah melakukan analisis metode pendekatan berbasis logika samar (fuzzy logic) dengan defuzzifikasi menggunakan algoritma artificial neural network untuk klasifikasi penggunaan lahan, serta mengkaji tingkat akurasi metode pendekatan berbasis logika samar (fuzzy logic) menggunakan algoritma artificial neural network yang melibatkan input data spektral ALOS AVNIR-2 dan data non spektral.
Penelitian ini dilakukan di sebagian wilayah Daerah Istimewa Yogyakarta dan sebagian wilayah Kabupaten Klaten. Input data yang dilibatkan berupa data spektral dan data non spektral yang berupa kemiringan lereng, solum tanah dan tekstur citra. Pemilihan input data yang dilibatkan berdasarkan asumsi bahwa perbedaan kemiringan lereng menggambarkan perbedaan penggunaan lahannya, untuk solum tanah dengan asumsi bahwa beda kedalaman solum beda pula penggunaan lahannya, sedangkan untuk tekstur citra diasumsikan bahwa pola tekstur yang berbeda menggambarkan penggunaan lahan yang berbeda juga.

Saat ini telah berkembang metode klasifikasi multispektral yang bisa dilakukan melalui berbagai pendekatan diantaranya menurut Jensen (2005) hard classification atau soft classifaction tergantung output yang dikehendaki, sedangkan berdasarkan distribusi datanya dapat menggunakan algoritma pendekatan parametrik misal maximum likelihood atau dengan pendekatan non parametrik misal jaringan syaraf tiruan (artificial neural network). Proses klasifikasi multispektral diproses dengan menggunakan bantuan perangkat komputer, menurut Danoedoro, P. (2012,hlm 295) berdasarkan tingkat otomatisasinya dapat dibedakan menjadi klasifikasi terselia (supervised classification) dan klasifikasi tak terselia (unsupervised classification). Jaringan syaraf tiruan (artificial neural network) merupakan salah satu pendekatan non parametrik dimana tidak mengharuskan distribusi statistik kelas digambarkan secara normal, kelebihan dari pendekatan non parametrik kemampuannya dalam menggabungkan data sepktral dan data non spektral, yang diasumsikan dengan menambah data non spektral maka akurasi yang dihasilkan juga meningkat. Algoritma klasifikasi multispektral berdasarkan pada asumsi distribusi datanya menurut Schowengerdts (1983) dapat dibedakan menjadi parametrik dan non parametrik. Algoritma parametrik mengamsusikan bahwa 
distribusi statistik kelas digambarkan dengan distribusi normal dan mengestimasikan parameter yang didistribusikan dengan vektor rerata dan matriks kovarian, sedangkan algoritma non parametrik tidak mengasumsikan distribusi kelas.

Arif (2011) menyebutkan bahwa jaringan syaraf tiruan memiliki kelebihan dalam menggabungkan data spektral dan non spketral, kemampuannya mengingat data berapapun jumlahnya data yang dilatihkan (memorisasi) serta mengenali data yang belum dilatihkan (generalisasi). sedangkan Kusumadewi (2004) menjelaskan bahwa jaringan syaraf merupakan salah satu representasi buatan dari otak manusia yang selalu mencoba untuk mensimulasikan proses pembelajaran pada otak manusia tersebut. Istilah buatan disini karena jaringan syaraf ini diimplementasikan dengan menggunakan program komputer yang mampu menyelesaikan sejumlah proses perhitungan selama pembelajaran, seperti halnya otak manusia jaringan syaraf juga terdiri dari beberapa neuron dan ada hubungan antara neuron-neuron tersebut. Neuron-neuron tersebut akan mentransformasikan informasi yang diterima melalui sambungan keluarnya menuju neuron-neuron yang lain, pada jaringan syaraf, hubungan ini dikenal dengan nama bobot.

Sebagai input data spektral pada penelitian ini menggunakan Citra ALOS AVNIR-2 yang merupakan citra penginderaan jauh yang memiliki resolusi spasial menengah, dan ada kecenderungan memiliki mixed pixel dimana dalam satu pikselnya bisa terdiri dari dua atau lebih jenis obyek. Metode pendekatan yang digunakan yaitu metode berbasis logika samar (fuzzy logic), dalam pengambilan sampelnya tidak harus piksel murni tapi dapat diambil pada mixed pixel sehingga tidak terjadi pemaksaan keanggotaan piksel untuk masuk ke dalam satu kelas saja ( soft classification). Sedangkan untuk proses defuzzifikasi menggunakan algoritma artificial neural network. Proses defuzzifikasi menurut Novamizanti et.al. (2010) merupakan proses mengubah fuzzy output menjadi crisp value. Fungsi aktivasi Jaringan Syaraf Tiruan menurut Kristanto (2004), diantaranya yaitu fungsi biner sigmoid. Fungsi ini digunakan untuk jaringan syaraf yang dilatih dengan menggunakan metode backpropagation, nilai output yang dihasilkan pada interval 0 sampai dengan 1. Beberapa penelitian terkait pendekatan logika samar (fuzzy logic) diantaranya Denaswidhi (2008) melakukan penelitian menggunakan pendekatan logika samar (fuzzy logic) untuk menurunkan informasi penggunaan lahan di sebagian Kota Semarang, eksekusi klasifikasi (defuzzifikasi) yang digunakan menggunakan algoritma maximum likelihood. Kurniawan (2012) melakukan penelitian tentang studi kemampuan fuzzy neural network dalam klasifikasi perpiksel penutup lahan dengan menggunakan Citra Landsat 7 ETM+. Samudra (2007) melakukan penelitian dengan menggunakan metode jaringan syaraf tiruan untuk klasifikasi penutup lahan dengan menggunakan Citra ASTER di Kota Salatiga dan sekitarnya, sedangkan variabel-variabel yang dilibatkan yaitu elevasi dan kemiringan lereng.

Informasi penggunaan lahan dari citra satelit tidak bisa langsung diterjemahkan dari kenampakan yang bisa dilihat pada citra tersebut. Danoedoro (1994 dalam Danoedoro 2012) menjelaskan bahwa skema klasifikasi yang secara langsung mengacu pada kategorikategori penggunaan lahan, atau yang mencampur adukkan aspek penutup lahan dan penggunaan lahan sebaiknya tidak digunakan pada klasifikasi awal, karena fungsi penggunaan lahan tidak bisa secara langsung direpresentasikan dengan nilai piksel. Oleh karena itu maka pengetahuan hubungan karaketristik antara penggunaan lahan dan penutup lahannya sangat diperlukan, selain itu menurut Bronsveld et al. (1994 dalam Danoedoro 2012) kondisi lapangan yang akan diamati atau local knowledge juga sangat penting dibutuhkan. Contoh hubungan antara penutup lahan dan penggunaan lahan dapat dilihat pada gambar 1 . 


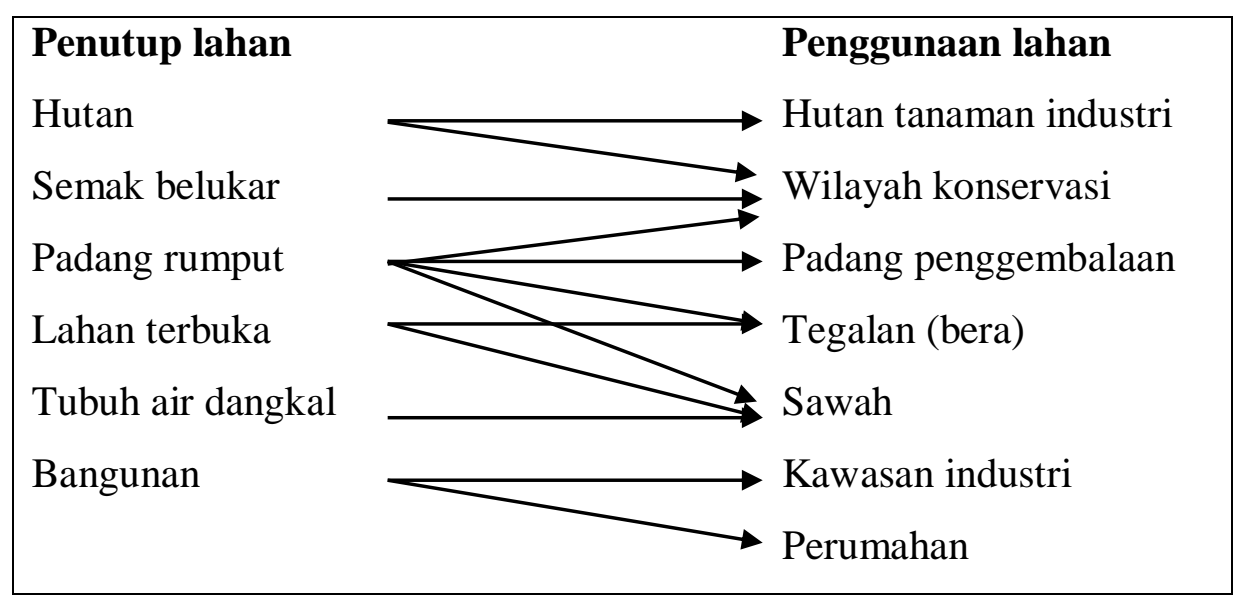

Sumber : Danoedoro, P. 2012, hlm 302

Gambar 1. Hubungan antara penutup lahan dan penggunaan lahan

Dari contoh hubungan antara penutup lahan dan penggunaan lahan pada gambar 1 tersebut, jika pada citra yang tampak adalah karakteristik penutup lahannya berupa hutan sedangkan penggunaan lahannya bisa jadi berupa hutan tanaman industri atau wilayah konservasi. Kemudian karakteristik penutup lahannya berupa bangunan, sedangkan penggunaan lahannya bisa merupakan kawasan industri atau permukiman.

Lahan menurut FAO (1976 dalam Hardjowigeno dkk.,2007) merupakan suatu lingkungan fisik termasuk iklim, relief, tanah, hidrologi, dan vegetasi alami yang semuanya secara potensial akan berpengaruh terhadap penggunaan lahan. Sedangkan karakteristik lahan atau sifat-sifat lahan menurut Arsyad (2010) yaitu atribut atau keadaan unsur-unsur lahan yang dapat diukur atau diperkirakan, diantaranya seperti temperature, curah hujan, tekstur tanah, kedalaman tanah, lereng, jenis vegetasi dan sebagainya.

\section{METODE PENELITIAN}

Penelitian ini mencoba mengkaji tingkat akurasi yang dihasilkan dengan menggunakan input yang berbasis fuzzy logic, sedangkan untuk proses defuzzifikasi menggunakan algoritma jaringan syaraf tiruan/artificial neural network atau sama saja dengan istilah fuzzy neural network, selain dicoba menggunakan input spektral (4 Band
Citra ALOS AVNIR-2), juga dicoba input tambahan yang bersifat data non spektral diantaranya data kemiringan lereng, solum tanah dan tekstur citra yang di-re-scale atau dibuat pada interval yang sama yaitu 0 sampai dengan 255 untuk semua input.

Data kemiringan lereng diperoleh dari data digital kontur peta RBI skala $1: 25.000$, kemudian data titik tinggi dari data kontur digital peta RBI skala $1: 25.000$ diinterpolasi pada software Idrisi Selva, untuk selanjutnya diubah ke slope. Data solum tanah diperoleh dari pengukuran langsung di lapangan, untuk selanjutnya dilakukan metode interpolasi data kedalaman solum tanah yang sudah ada pada software Idrisi Selva, Tekstur citra diperoleh dengan menggunakan teknik analisis variability berdasarkan texture measure tipe diversity dengan area calculation $7 \times 7$ yang terdapat pada software Idrisi Selva. Skema penggunaan lahan yang sudah dimodifiksi dengan acuan, Norma, Standar, Prosedur dan Kriteria yang dibuat oleh Direktorat Pemetaan Tematik BPN RI dapat dilihat pada tabel 1, sedangkan alur penelitian dapat dilihat pada gambar 3 .

Penelitian ini menggunakan metode multilayer perceptron dengan algoritma backpropagation, contoh arsitektur jaringan syaraf tiruan (JST) dapat dilihat pada gambar 2. 
Tabel 1.Skema klasifikasi penggunaan lahan yang digunakan dalam penelitian (modifikasi atas klasifikasi penggunaan lahan BPN RI)

\begin{tabular}{|c|l|l|c|}
\hline No. & \multicolumn{1}{|c|}{ Identifikasi penutup lahan } & Kelas Penggunaan Lahan & Singkatan \\
\hline 1 & Vegetasi berkayu kerapatan rendah & tegalan/ladang & $\mathrm{Tg}$ \\
\hline 2 & Vegetasi berkayu kerapatan rendah & Semak & $\mathrm{sm}$ \\
\hline 3 & Atap genteng & Permukiman & $\mathrm{pm}$ \\
\hline 4 & Aspal & tanah jasa & $\mathrm{Tj}$ \\
\hline 5 & Vegetasi tak berkayu kerapatan sedang & tempat olahraga & to \\
\hline 6 & Vegetasi tak berkayu kerapatan tinggi & sawah irigasi & $\mathrm{si}$ \\
\hline 7 & Vegetasi berkayu kerapatan tinggi & kebun campuran & $\mathrm{kc}$ \\
\hline 8 & Atap genteng & Peternakan & $\mathrm{pt}$ \\
\hline 9 & Atap asbes & tanah industri & ti \\
\hline 10 & Air dangkal & $\begin{array}{l}\text { pemanfaatan berbasis air } \\
\text { tergenang }\end{array}$ & at \\
\hline 11 & Air dangkal & $\begin{array}{l}\text { pemanfaatan } \\
\text { sungai }\end{array}$ & $\mathrm{serbasis}$ \\
\hline 12 & $\begin{array}{l}\text { Tanah terbuka dan kering dan vegetasi } \\
\text { berkayu kerapatan rendah }\end{array}$ & sawah non irigasi & sn \\
\hline 13 & Vegetasi berkayu kerapatan tinggi & $\begin{array}{l}\text { Tanah terbuka dan kering dan lahan } \\
\text { terbangun }\end{array}$ & penggunaan lain \\
\hline
\end{tabular}

Sumber : BPN RI, 2012 dengan modifikasi

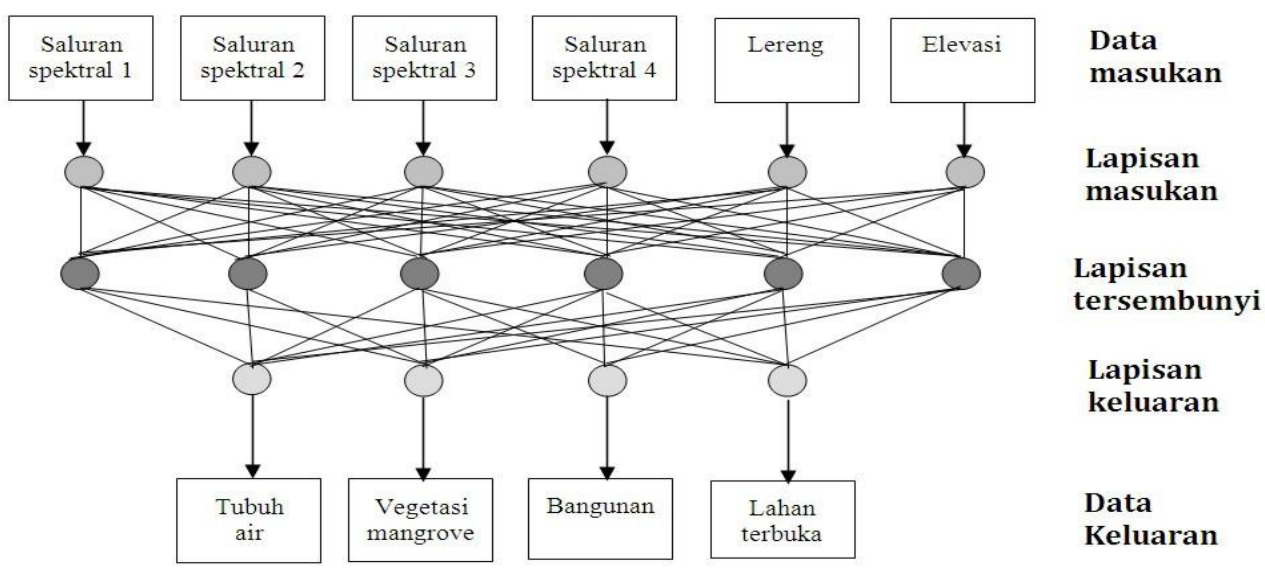

Sumber : Danoedoro, P. 2012, hlm 352

Gambar 2. Contoh arsitektur jaringan syaraf tiruan (JST) 


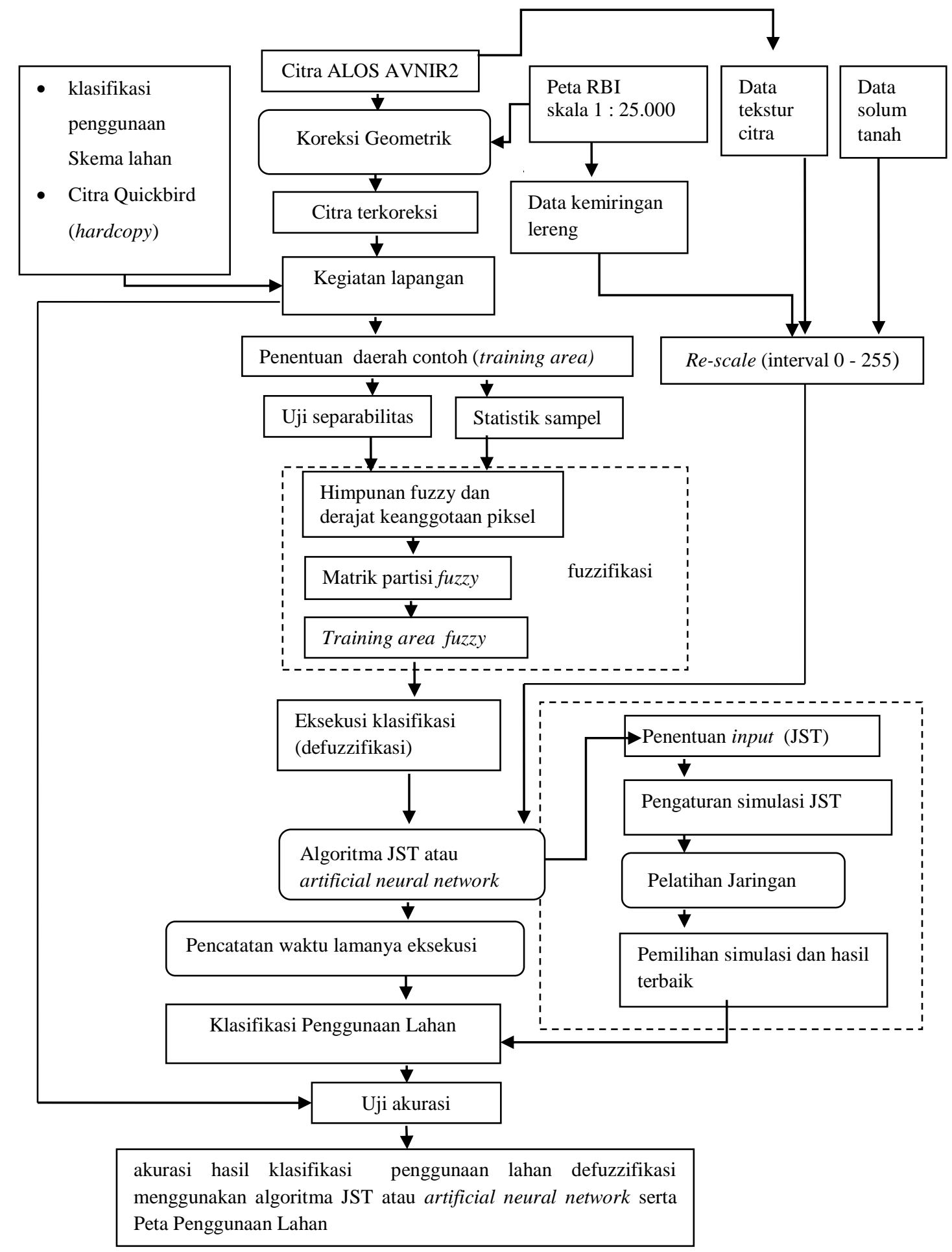

Gambar 3. Diagram alir penelitian

\section{Backpropagation menurut} Kusumadewi (2004) merupakan algoritma pembelajaran yang terawasi dan biasanya digunakan oleh percepteron dengan banyak lapisan untuk mengubah bobot-bobot yang terhubung dengan neuron-neuron yang ada pada lapisan tersembunyinya. Algoritma backpropagation menggunakan error output untuk mengubah nilai bobot-bobotnya dalam arah mundur (backward). Untuk mendapatkan error ini, tahap perambatan maju (forward propagation) harus dikerjakan terlebih dahulu.

Parameter-parameter jaringan yang digunakan untuk batasan dalam prosesnya yaitu:

1. Iterasi adalah jumlah perulangan yang dilakukan selama pelatihan data dalam klasifikasi penggunaan lahan. Dalam penelitian ini akan dicoba dengan jumlah 
iterasi 10000 kali (set as default pada software Idrisi Selva). Jumlah iterasi sangat mempengaruhi waktu yang diperlukan dalam pelatihan dan pengujian jaringan, semakin besar iterasi yang dilakukan semakin lama waktu yang diperlukan dalam proses pelatihan jaringan.

2. Learning rate atau konstanta pembelajaran yang digunakan dalam penelitian ini dibatasi antara 0,005 sampai dengan 0,5. Semakin besar nilai learning rate maka bias antara training RMS dan testing RMS semakin besar, selain itu semakin cepat pula proses pembelajarannya.

3. Metode aktivasi yang digunakan pada penelitian ini yaitu fungsi aktivasi sigmoid. Data yang digunakan adalah data yang bersifat kontinyu maka fungsi sigmoid umumnya sering digunakan karena sifat fungsional exponensialnya yang tidak memasuki daerah jenuh (bersifat konvergen), dengan garis singgung antara 0 sampai dengan 1 atau -1 sampai dengan 1 .

4. Nilai momentum ditentukan pada nilai 0,5 , semakin besar momentum maka proses semakin cepat dan juga RMS semakin besar.

5. Nilai RMS stopping criteria ditentukan pada nilai 0,001 , iterasi akan berhenti jika nilai RMS lebih kecil daripada nilai batas toleransi yang ditetapkan.

6. Lapisan tersembunyi (hidden layer) adalah lapisan yang menerima respon berupa bobot dari lapisan input untuk diteruskan pada lapisan output. Jumlah hidden layer yang digunakan dalam penelitian ini satu hidden layer, karena semakin banyak hidden layer yang dilibatkan hanya akan menambah waktu pelatihan.

Metode yang digunakan untuk menghitung akurasi klasifikasi dengan menggunakan matriks kesalahan atau confusion matrix/error matrix, untuk selanjutnya dilakukan perhitungan producer's accuracy, user's accuracy, overall accuracy dan nilai indeks kappa. Producer's accuracy merupakan akurasi yang dilihat dari sisi penghasil peta, sedangkan user's accuracy merupakan akurasi yang dilihat dari sisi pengguna petanya.

\section{HASIL DAN PEMBAHASAN}

Berikut input data non spektral yang digunakan beserta hasilnya :

\section{Kemiringan Lereng}

Data kemiringan lereng diperoleh dengan dua metode, yang hasil dari kedua metode tersebut nanti digunakan untuk melihat perbandingan hasil akurasinya. Metode yang pertama yaitu diperoleh dari data titik tinggi dari data kontur digital peta RBI skala $1: 25.000$ untuk kemudian diambil titik ketinggiannya pada software Idrisi Selva dapat dilihat pada gambar 4. Metode yang kedua yaitu dari data kontur digital peta RBI skala 1 : 25.000 diproses menggunakan metode topo to raster kemudian diubah menjadi slope pada software ArcGIS, selanjutnya diubah kedalam format .img agar bisa dibuka pada software Idrisi untuk kemudian diubah kedalam format raster atau .rst yang dapat dilihat pada gambar 5 .

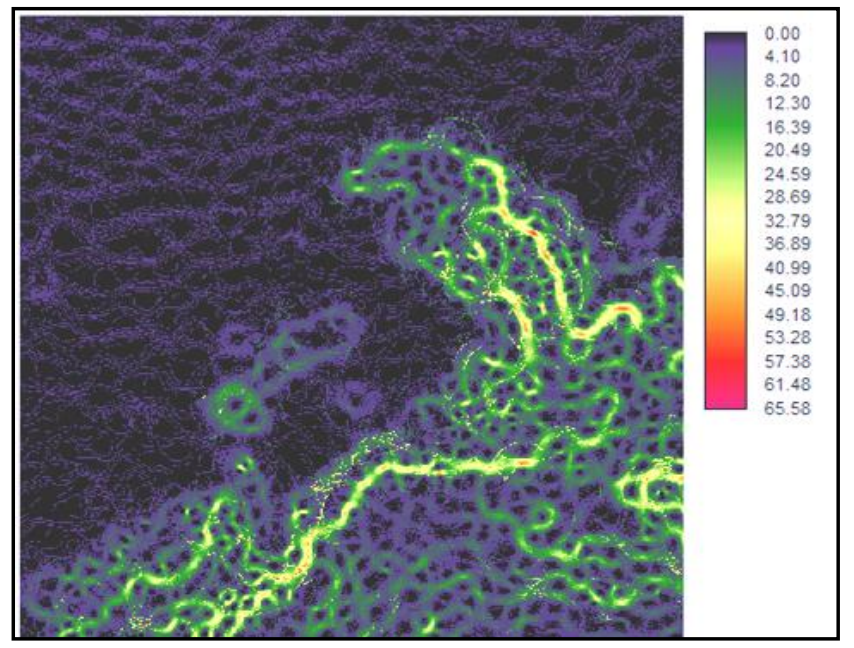

Gambar 4. Data slope hasil pengolahan pada software Idrisi Selva 


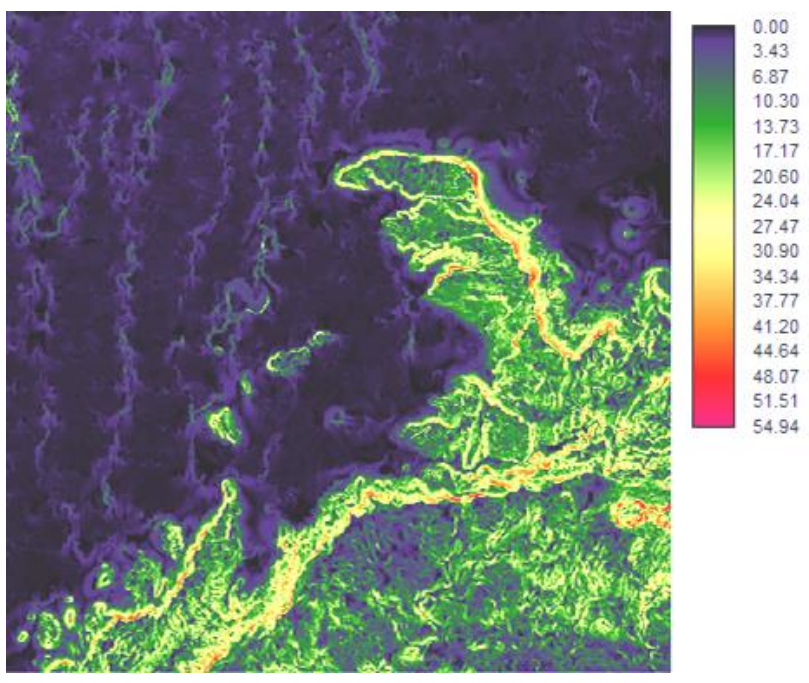

Gambar 5. Data slope hasil pengolahan dari software ArcGIS di-import pada software Idrisi Selva

Gradasi warna dari biru tua hingga warna merah menunjukkan bahwa semakin warnanya merah maka kemiringan lereng semakin curam sedangkan semakin ke arah warna biru tua menunjukkan bahwa kemiringan lereng semakin datar.

\section{Solum Tanah}

Data solum tanah diperoleh dengan melakukan pengukuran secara langsung di lapangan, dengan mengisi formulir yang sudah dibuat sebelum pergi ke lapangan. Data solum tanah tersebut diambil secara acak dan merata diseluruh wilayah kajian sebanyak 50 sampel. Selanjutnya data solum tanah tersebut diinterpolasi pada software Idrisi Selva.

Solum tanah merupakan indikator potensi kedalaman akar tanaman untuk berpenetrasi, makin dangkal berarti makin tipis sistem perakarannya, sehingga semakin besar bobot atau tinggi tanaman akan semakin mudah tumbang (Sartohadi, 2006), dengan penjelasan tersebut maka diasumsikan bahwa untuk tanah dengan solum dangkal tidak mungkin ditanami pohon yang berbobot besar atau tinggi hanya cocok untuk jenis padipadian atau sejenisnya yang berbobot rendah, atau juga cocok untuk permukiman apabila kemiringan lereng datar. Hal tersebut juga mengasumsikan beda kedalaman solum beda pula penggunaan lahannya. Data kedalaman solum tanah diperoleh dari pengukuran langsung di lapangan sebanyak 50 sampel, data dapat dilihat pada tabel 2. Solum tanah diukur dari horizon $\mathrm{O}$ hingga menemukan lapisan batuan (horizon R) untuk solum tanah yang dalam maka dicari profil penampang samping yang bisa dilihat di kanan/kiri sungai sekitar tempat titik pengambilan sampel solum tanah.

Tabel 2. Titik-titik sampel kedalaman solum tanah

\begin{tabular}{cccc}
\hline No. & $\mathbf{X}$ & $\mathbf{Y}$ & \multicolumn{2}{c}{ Kedalaman solum tanah $(\mathbf{c m})$} \\
\hline 1 & 435897 & 9141882 & 150 \\
2 & 435990 & 9143125 & 150 \\
3 & 437239 & 9139850 & 90 \\
4 & 437943 & 9139667 & 120 \\
5 & 438101 & 9140484 & 110 \\
6 & 439254 & 9141870 & 150 \\
7 & 440143 & 9141846 & 110 \\
8 & 440560 & 9140400 & 150 \\
9 & 442448 & 9142291 & 120 \\
\hline
\end{tabular}




\begin{tabular}{|c|c|c|c|}
\hline 10 & 444219 & 9144245 & 110 \\
\hline 11 & 445137 & 9144058 & 110 \\
\hline 12 & 446555 & 9143618 & 100 \\
\hline 13 & 447353 & 9142522 & 110 \\
\hline 14 & 443023 & 9144259 & 120 \\
\hline 15 & 443959 & 9141692 & 50 \\
\hline 16 & 445312 & 9141411 & 61 \\
\hline 17 & 445408 & 9141396 & 53 \\
\hline 18 & 445760 & 9141337 & 68 \\
\hline 19 & 446404 & 9140517 & 44 \\
\hline 20 & 447500 & 9139955 & 54 \\
\hline 21 & 446006 & 9141552 & 65 \\
\hline 22 & 443154 & 9140362 & 50 \\
\hline 23 & 443683 & 9139632 & 48 \\
\hline 24 & 443886 & 9138916 & 51 \\
\hline 25 & 444379 & 9138176 & 45 \\
\hline 26 & 445060 & 9136423 & 87 \\
\hline 27 & 445083 & 9135427 & 38 \\
\hline 28 & 445299 & 9135317 & 80 \\
\hline 29 & 443034 & 9133725 & 34 \\
\hline 30 & 437635 & 9134768 & 150 \\
\hline 31 & 441386 & 9139384 & 120 \\
\hline 32 & 439550 & 9134175 & 95 \\
\hline 33 & 442754 & 9131987 & 120 \\
\hline 34 & 443055 & 9131502 & 50 \\
\hline 35 & 444477 & 9130109 & 135 \\
\hline 36 & 443880 & 9130895 & 150 \\
\hline 37 & 444750 & 9129981 & 130 \\
\hline 38 & 440986 & 9130487 & 160 \\
\hline 39 & 440987 & 9130876 & 43 \\
\hline 40 & 442240 & 9133384 & 155 \\
\hline 41 & 437554 & 9130567 & 80 \\
\hline 42 & 437054 & 9129657 & 42 \\
\hline 43 & 438654 & 9132112 & 32 \\
\hline 44 & 448747 & 9136428 & 50 \\
\hline 45 & 447490 & 9133980 & 48 \\
\hline 46 & 438461 & 9137387 & 130 \\
\hline 47 & 440776 & 9136361 & 50 \\
\hline 48 & 442496 & 9136560 & 150 \\
\hline 49 & 440942 & 9138015 & 150 \\
\hline 50 & 446961 & 9131830 & 110 \\
\hline
\end{tabular}


Interpolasi solum tanah dilakukan pada software Idrisi Selva dapat dilihat pada Gambar 6.

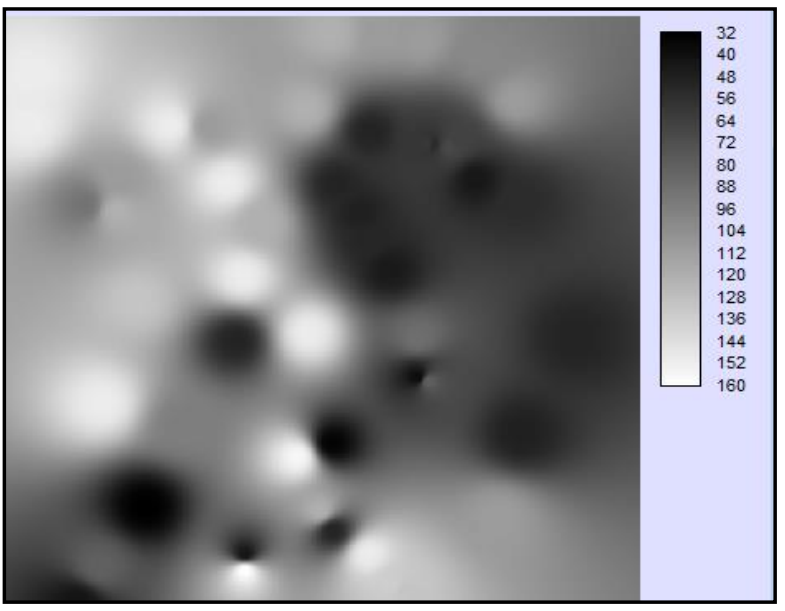

Gambar 6. Data solum tanah hasil pengolahan pada software Idrisi Selva

Dari gambar 6 terlihat adanya gradasi warna dari warna hitam (gelap) ke warna putih (cerah), hal tersebut menggambarkan bahwa semakin gelap maka semakin dangkal kedalaman solum tanahnya, sebaliknya semakin cerah semakin dalam.

\section{Tekstur Citra}

Tekstur citra diperoleh dengan menggunakan teknik analisis variability berdasarkan texture measure tipe diversity dengan area calculation $7 \times 7$ yang terdapat pada software Idrisi Selva, hasil proses dapat dilihat pada gambar 14.

Teknik ini dipilih dengan asumsi bahwa perbedaaan pola-pola tekstur yang didapatkan menggambarkan perbedaan penggunaan lahannya. Seperti yang terlihat pada gambar 7, pola-pola tekstur bisa dilihat pada perubahan rona dari warna hitam (gelap) ke arah putih (cerah) tampak sangat jelas

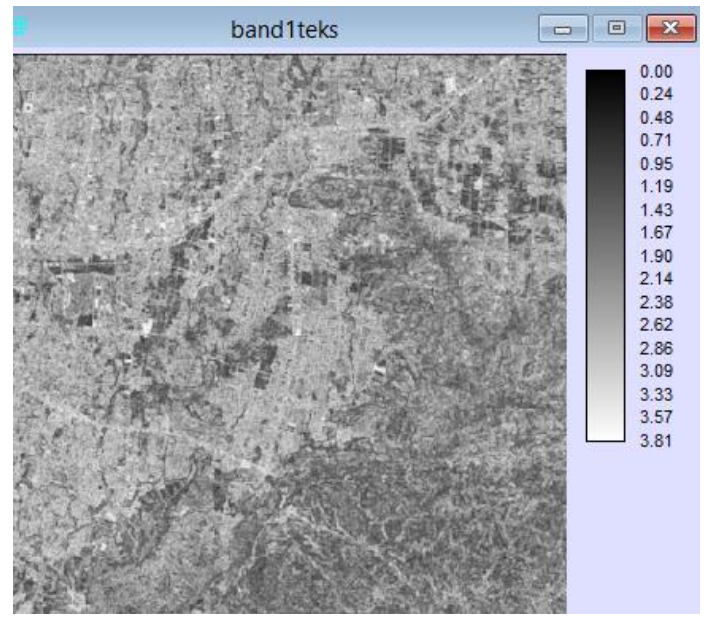

pola-pola tekstur yang tergambar pada tekstur citra band 1 ALOS AVNIR-2 untuk yang bervegetasi tampak agak gelap sedangkan yang tidak bervegetasi tampak cerah seperti jalan dan permukiman. Tetapi di tekstur citra band 4 ALOS AVNIR-2 pola tekstur tidak begitu tampak jelas apabila dibandingkan dengan tekstur citra band 2 dan band 3 .

Kelebihan dari metode jaringan syaraf tiruan adalah bisa mengolah data spektral yang dipadukan dengan data non spektral. Input data spektral yang digunakan dalam penelitian ini yaitu 4 band yang dimiliki oleh Citra ALOS AVNIR-2, sedangkan data non spektral yang dilibatkan adalah kemiringan lereng, solum tanah dan tekstur citra. Tampilan untuk eksekusi MLP (Multi Layer Perceptron) pada software Idrisi Selva dapat dilihat pada gambar 8 .

Pengaturan parameter simulasi pada penelitian ini hanya satu hidden layer, momentum factor diatur pada nilai 0,5 , sigmoid constant sama dengan 1, RMS stopping criteria diatur pada nilai 0,001 sedangkan iterasi dibatasi sebanyak 10000 kali iterasi, sedangkan learning rate diatur pada nilai 0,005 sampai dengan 0,05. Untuk 14 kelas penggunaan lahan dengan input data spektral jumlah layer node yaitu 7 dan 14, sedangkan dengan input data spektral dan non spektral jumlah layer node 12 dan 24 . Pengaturan simulasi dan perhitungan waktu eksekusi untuk 14 kelas penggunaan lahan dapat dilihat pada tabel 3, 4, dan 5 sedangkan untuk perhitungan overall accuracy dan indeks kappa masing-masing simulasi dapat dilihat pada tabel 5, 6 dan 7 .

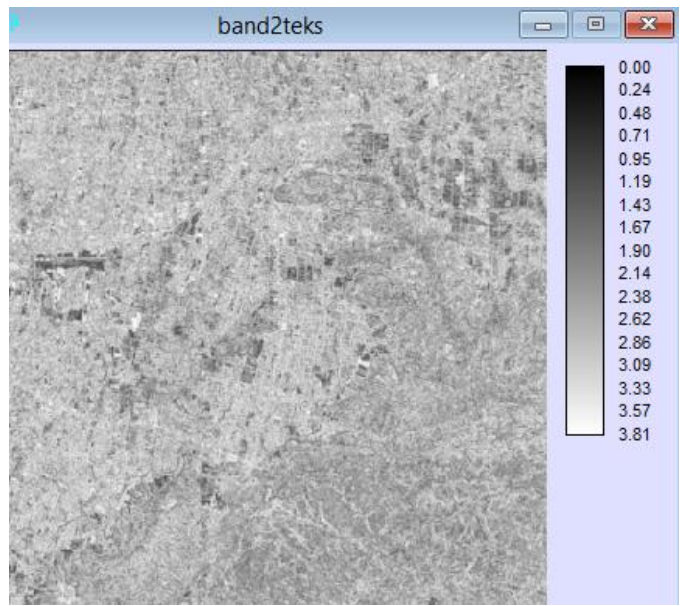



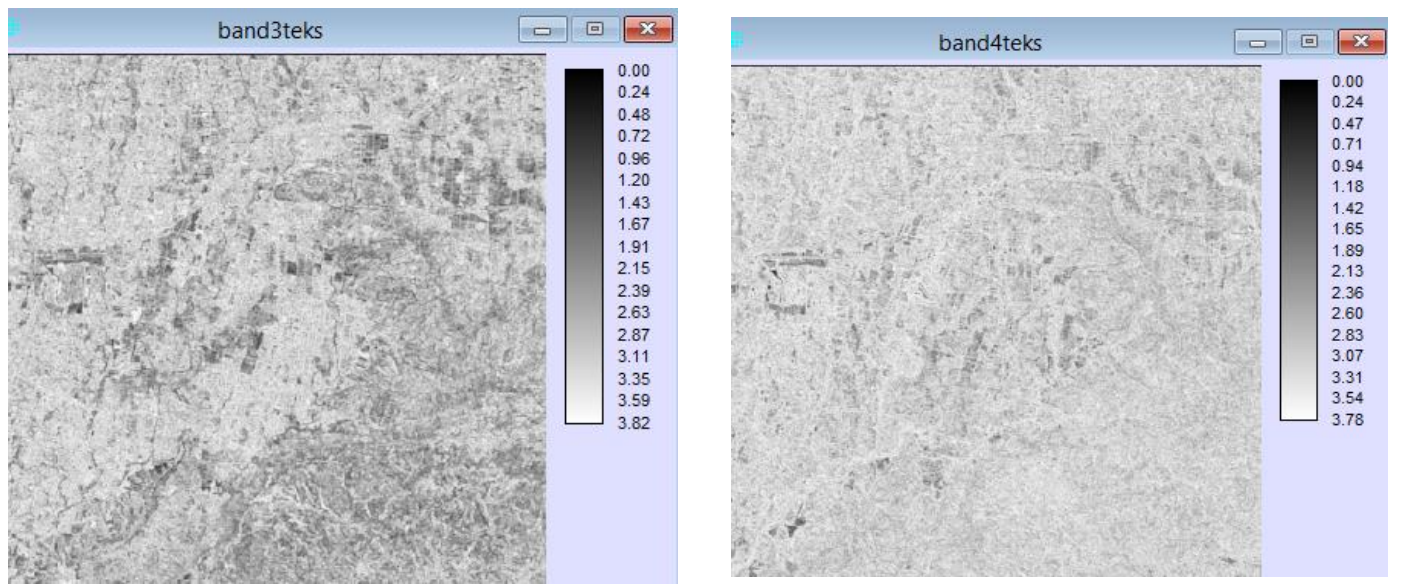

Gambar 7. Tekstur citra hasil pengolahan Citra ALOS AVNIR-2 pada software Idrisi Selva

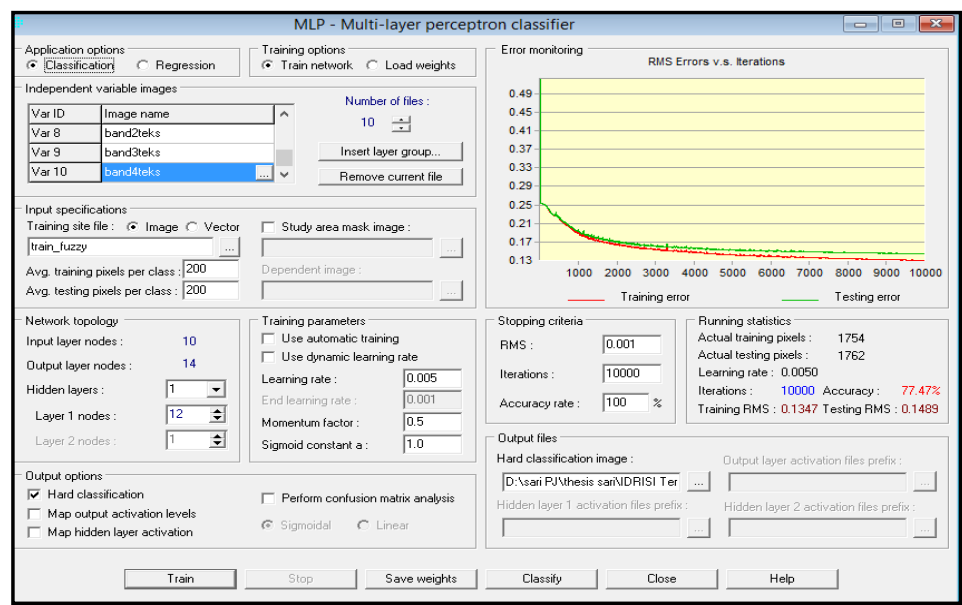

Gambar 8. Tampilan pengaturan eksekusi MLP (Multi Layer Perceptron) pada software Idrisi Selva 
Tabel 3. Simulasi parameter JST untuk 14 kelas penggunaan lahan dengan input 4 band spektral

\begin{tabular}{|c|c|c|c|c|c|c|c|c|c|c|c|}
\hline $\begin{array}{l}\text { No. Simulasi } \\
\text { dan Hasilnya }\end{array}$ & $\begin{array}{l}\text { Hidden } \\
\text { layer }\end{array}$ & $\begin{array}{l}\text { Layer } \\
\text { node }\end{array}$ & $\begin{array}{l}\text { Learning } \\
\text { rate }\end{array}$ & $\begin{array}{l}\text { Momentum } \\
\text { factor }\end{array}$ & $\begin{array}{l}\text { Sigmoid } \\
\text { constant }\end{array}$ & RMS & Iterasi & Akurasi & $\begin{array}{l}\text { Training } \\
\text { RMS }\end{array}$ & $\begin{array}{l}\text { Testing } \\
\text { RMS }\end{array}$ & Time \\
\hline FNN1 & 1 & 7 & 0,005 & 0,5 & 1 & 0,001 & 10000 & 60,27 & 0,2074 & 0,208 & 00.02 .32 \\
\hline FNN2 & 1 & 7 & 0,006 & 0,5 & 1 & 0,001 & 10000 & 51,53 & 0,2096 & 0,2115 & 00.02 .32 \\
\hline FNN3 & 1 & 7 & 0,007 & 0,5 & 1 & 0,001 & 10000 & 59,88 & 0,2053 & 0,2041 & 00.02 .32 \\
\hline FNN4 & 1 & 7 & 0,008 & 0,5 & 1 & 0,001 & 10000 & 58,8 & 0,2047 & 0,2058 & 00.02 .32 \\
\hline FNN5 & 1 & 7 & 0,009 & 0,5 & 1 & 0,001 & 10000 & 55,9 & 0,2056 & 0,2052 & 00.02 .32 \\
\hline FNN6 & 1 & 7 & 0,01 & 0,5 & 1 & 0,001 & 10000 & 59,19 & 0,2029 & 0,2051 & 00.02 .32 \\
\hline FNN7 & 1 & 7 & 0,02 & 0,5 & 1 & 0,001 & 10000 & 54,03 & 0,2092 & 0,211 & 00.02 .32 \\
\hline FNN8 & 1 & 7 & 0,03 & 0,5 & 1 & 0,001 & 10000 & 44,44 & 0,2271 & 0,2268 & 00.02 .32 \\
\hline FNN9 & 1 & 7 & 0,04 & 0,5 & 1 & 0,001 & 10000 & 8,23 & 0,2673 & 0,2673 & 00.02 .33 \\
\hline FNN10 & 1 & 14 & 0,005 & 0,5 & 1 & 0,001 & 10000 & 61,52 & 0,2003 & 0,2014 & 00.04 .14 \\
\hline FNN11 & 1 & 14 & 0,006 & 0,5 & 1 & 0,001 & 10000 & 61,24 & 0,1974 & 0,2012 & 00.04 .13 \\
\hline FNN12 & 1 & 14 & 0,007 & 0,5 & 1 & 0,001 & 10000 & 63 & 0,1979 & 0,1979 & 00.04 .13 \\
\hline FNN13 & 1 & 14 & 0,008 & 0,5 & 1 & 0,001 & 10000 & 60,9 & 0,2016 & 0,2039 & 00.04 .13 \\
\hline FNN14 & 1 & 14 & 0,009 & 0,5 & 1 & 0,001 & 10000 & 58,06 & 0,1996 & 0,2032 & 00.04 .13 \\
\hline FNN15 & 1 & 14 & 0,01 & 0,5 & 1 & 0,001 & 10000 & 62,15 & 0,1994 & 0,2011 & 00.04 .14 \\
\hline FNN16 & 1 & 14 & 0,02 & 0,5 & 1 & 0,001 & 10000 & 7,6 & 0,2673 & 0,2673 & 00.04 .13 \\
\hline
\end{tabular}


Tabel 4. Simulasi parameter JST untuk 14 kelas penggunaan lahan dengan input 4 band spektral dan data non spektral (metode interpolasi langsung di Idrisi Selva untuk data kemiringan lereng dan solum tanah)

\begin{tabular}{|c|c|c|c|c|c|c|c|c|c|c|c|}
\hline $\begin{array}{l}\text { No. simulasi } \\
\text { dan hasilnya }\end{array}$ & $\begin{array}{c}\text { Hidden } \\
\text { layer }\end{array}$ & $\begin{array}{l}\text { Layer } \\
\text { node }\end{array}$ & $\begin{array}{l}\text { Learning } \\
\text { rate }\end{array}$ & $\begin{array}{l}\text { Momentum } \\
\text { factor }\end{array}$ & $\begin{array}{l}\text { Sigmoid } \\
\text { constant }\end{array}$ & RMS & Iterasi & Akurasi & $\begin{array}{c}\text { Training } \\
\text { RMS }\end{array}$ & $\begin{array}{c}\text { Testing } \\
\text { RMS }\end{array}$ & Time \\
\hline FNNNS1 & 1 & 12 & 0,005 & 0,5 & 1 & 0,001 & 10000 & 80,99 & 0,1376 & 0,1453 & 00.04 .29 \\
\hline FNNNS2 & 1 & 12 & 0,006 & 0,5 & 1 & 0,001 & 10000 & 82,18 & 0,1238 & 0,1416 & 00.04 .29 \\
\hline FNNNS3 & 1 & 12 & 0,007 & 0,5 & 1 & 0,001 & 10000 & 80,7 & 0,1329 & 0,1448 & 00.04 .29 \\
\hline FNNNS4 & 1 & 12 & 0,008 & 0,5 & 1 & 0,001 & 10000 & 83,71 & 0,1251 & 0,1319 & 00.04 .28 \\
\hline FNNNS5 & 1 & 12 & 0,009 & 0,5 & 1 & 0,001 & 10000 & 79,51 & 0,1254 & 0,1377 & 00.04 .28 \\
\hline FNNNS6 & 1 & 12 & 0,01 & 0,5 & 1 & 0,001 & 10000 & 84,73 & 0,125 & 0,1335 & 00.04 .29 \\
\hline FNNNS7 & 1 & 12 & 0,02 & 0,5 & 1 & 0,001 & 10000 & 7,6 & 0,2673 & 0,2673 & 00.04 .29 \\
\hline FNNNS8 & 1 & 24 & 0,005 & 0,5 & 1 & 0,001 & 10000 & 85,3 & 0,1161 & 0,122 & 00.08 .03 \\
\hline FNNNS9 & 1 & 24 & 0,006 & 0,5 & 1 & 0,001 & 10000 & 83,71 & 0,1177 & 0,1288 & 00.08 .04 \\
\hline FNNNS10 & 1 & 24 & 0,007 & 0,5 & 1 & 0,001 & 10000 & 74,35 & 0,1437 & 0,1532 & 00.08 .03 \\
\hline FNNNS11 & 1 & 24 & 0,008 & 0,5 & 1 & 0,001 & 10000 & 85,58 & 0,1155 & 0,1245 & 00.08 .03 \\
\hline FNNNS12 & 1 & 24 & 0,009 & 0,5 & 1 & 0,001 & 10000 & 7,26 & 0,2673 & 0,2673 & 00.08 .03 \\
\hline
\end{tabular}


H. Wulansari. Metode Defuzzifikasi Artificial Neural Network...

Tabel 5. Simulasi parameter JST untuk 14 kelas penggunaan lahan dengan input 4 band spektral dan data non spektral (metode interpolasi di ArcGIS untuk data kemiringan lereng dan solum tanah)

\begin{tabular}{|c|c|c|c|c|c|c|c|c|c|c|c|}
\hline $\begin{array}{l}\text { No. simulasi dan } \\
\text { hasilnya }\end{array}$ & $\begin{array}{c}\text { Hidden } \\
\text { layer }\end{array}$ & $\begin{array}{c}\text { Layer } \\
\text { node }\end{array}$ & Learning rate & $\begin{array}{l}\text { Momentum } \\
\text { factor }\end{array}$ & $\begin{array}{l}\text { Sigmoid } \\
\text { constant }\end{array}$ & RMS & Iterasi & Akurasi & $\begin{array}{c}\text { Training } \\
\text { RMS }\end{array}$ & $\begin{array}{c}\text { Testing } \\
\text { RMS }\end{array}$ & Time \\
\hline FNNNS1 & 1 & 12 & 0,005 & 0,5 & 1 & 0,001 & 10000 & 79,28 & 0,1182 & 0,1456 & 00.03 .34 \\
\hline FNNNS2 & 1 & 12 & 0,006 & 0,5 & 1 & 0,001 & 10000 & 81,59 & 0,1233 & 0,1406 & 00.03 .35 \\
\hline FNNNS3 & 1 & 12 & 0,007 & 0,5 & 1 & 0,001 & 10000 & 82,12 & 0,1218 & 0,1366 & 00.03 .34 \\
\hline FNNNS4 & 1 & 12 & 0,008 & 0,5 & 1 & 0,001 & 10000 & 80,7 & 0,1239 & 0,1405 & 00.03 .34 \\
\hline FNNNS5 & 1 & 12 & 0,009 & 0,5 & 1 & 0,001 & 10000 & 83,95 & 0,1215 & 0,1331 & 00.03 .34 \\
\hline FNNNS6 & 1 & 12 & 0,01 & 0,5 & 1 & 0,001 & 10000 & 81,56 & 0,1273 & 0,1427 & 00.03 .34 \\
\hline FNNNS7 & 1 & 12 & 0,02 & 0,5 & 1 & 0,001 & 10000 & 81,55 & 0,1265 & 0,1413 & 00.03 .34 \\
\hline FNNNS8 & 1 & 12 & 0,03 & 0,5 & 1 & 0,001 & 10000 & 6,6 & 0,2673 & 0,2673 & 00.03 .34 \\
\hline FNNNS9 & 1 & 24 & 0,005 & 0,5 & 1 & 0,001 & 10000 & 87,39 & 0,1042 & 0,1209 & 00.06 .24 \\
\hline FNNNS10 & 1 & 24 & 0,006 & 0,5 & 1 & 0,001 & 10000 & 82,98 & 0,1119 & 0,1361 & 00.06 .24 \\
\hline FNNNS11 & 1 & 24 & 0,007 & 0,5 & 1 & 0,001 & 10000 & 81,88 & 0,1223 & 0,1367 & 00.06 .24 \\
\hline FNNNS12 & 1 & 24 & 0,008 & 0,5 & 1 & 0,001 & 10000 & 82,41 & 0,1251 & 0,1358 & 00.06 .24 \\
\hline FNNNS13 & 1 & 24 & 0,009 & 0,5 & 1 & 0,001 & 10000 & 79,74 & 0,1286 & 0,1425 & 00.06 .23 \\
\hline FNNNS14 & 1 & 24 & 0,01 & 0,5 & 1 & 0,001 & 10000 & 79,19 & 0,1353 & 0,1427 & 00.06 .23 \\
\hline FNNNS15 & 1 & 24 & 0,02 & 0,5 & 1 & 0,001 & 10000 & 7,3 & 0,2673 & 0,2673 & 00.06 .24 \\
\hline
\end{tabular}


Tabel 5. Overall accuracy dan indeks kappa masing-masing simulasi untuk 14 kelas penggunaan lahan dengan input 4 band spektral

\begin{tabular}{|c|r|r|}
\hline $\begin{array}{c}\text { Hasil } \\
\text { simulasi }\end{array}$ & $\begin{array}{r}\text { Overall } \\
\text { accuracy }\end{array}$ & $\begin{array}{c}\text { Indeks } \\
\text { kappa }\end{array}$ \\
\hline FNN1 & 51,66 & 0,47 \\
\hline FNN2 & 48,78 & 0,44 \\
\hline FNN3 & 47,01 & 0,43 \\
\hline FNN4 & 48,78 & 0,45 \\
\hline FNN5 & 49,31 & 0,45 \\
\hline FNN6 & 51,69 & 0,47 \\
\hline FNN7 & 53,09 & 0,49 \\
\hline FNN8 & 45,97 & 0,41 \\
\hline FNN9 & 0 & 0 \\
\hline FNN10 & 52,86 & 0,49 \\
\hline FNN11 & 54,73 & 0,51 \\
\hline FNN12 & 53,43 & 0,49 \\
\hline FNN13 & 55 & 0,51 \\
\hline FNN14 & 52,12 & 0,48 \\
\hline FNN15 & 52,49 & 0,49 \\
\hline FNN16 & 0 & 0 \\
\hline Fumbr & & 0,49 \\
\hline
\end{tabular}

Sumber : Pengolahan penelitian, 2013

Dari tabel 5 overall accuracy terbaik untuk 14 kelas penggunaan lahan dengan input data spektral diperoleh pada simulasi ke 13 dengan overall accuracy $55 \%$ dan indeks kappa 0,51.

Tabel 6. Overall accuracy dan indeks kappa masing-masing simulasi untuk 14 kelas penggunaan lahan dengan input 4 band spektral dan data non spektral (metode interpolasi data kemiringan lereng dan solum tanah di Idrisi Selva)

\begin{tabular}{|c|r|r|}
\hline $\begin{array}{c}\text { Hasil } \\
\text { simulasi }\end{array}$ & $\begin{array}{c}\text { Overall } \\
\text { accuracy }\end{array}$ & $\begin{array}{c}\text { Indeks } \\
\text { kappa }\end{array}$ \\
\hline FNNNS1 & 37,84 & 0,31 \\
\hline FNNNS2 & 40,08 & 0,34 \\
\hline FNNNS3 & 38,17 & 0,31 \\
\hline FNNNS4 & 40,52 & 0,35 \\
\hline FNNNS5 & 34,26 & 0,28 \\
\hline
\end{tabular}

\begin{tabular}{|c|r|r|}
\hline FNNNS6 & 36,84 & 0,31 \\
\hline FNNNS7 & 0 & 0 \\
\hline FNNNS8 & 36,37 & 0,30 \\
\hline FNNNS9 & 40,88 & 0,35 \\
\hline FNNNS10 & 32,18 & 0,25 \\
\hline FNNNS11 & 34,16 & 0,28 \\
\hline FNNNS12 & 0 & 0 \\
\hline
\end{tabular}

Sumber : Pengolahan penelitian, 2013

Dari tabel 6 overall accuracy terbaik untuk 14 kelas penggunaan lahan dengan input data spektral dan data non spektral (metode interpolasi langsung di Idrisi Selva) diperoleh pada simulasi ke 9 dengan overall accuracy 40,88\% dan indeks kappa 0,35.

Tabel 7. Overall accuracy dan indeks kappa masing-masing simulasi untuk 14 kelas penggunaan lahan dengan input 4 band spektral dan data non spektral (metode interpolasi data kemiringan lereng dan solum tanah di ArcGIS)

\begin{tabular}{|c|r|r|}
\hline $\begin{array}{c}\text { Hasil } \\
\text { simulasi }\end{array}$ & $\begin{array}{c}\text { Overall } \\
\text { accuracy }\end{array}$ & \multicolumn{1}{c|}{$\begin{array}{c}\text { Indeks } \\
\text { kappa }\end{array}$} \\
\hline FNNNS1 & 39,14 & 0,34 \\
\hline FNNNS2 & 39,48 & 0,34 \\
\hline FNNNS3 & 40,78 & 0,36 \\
\hline FNNNS4 & 42,76 & 0,38 \\
\hline FNNNS5 & 43,36 & 0,38 \\
\hline FNNNS6 & 41,49 & 0,36 \\
\hline FNNNS7 & 47,01 & 0,42 \\
\hline FNNNS8 & 0 & 0 \\
\hline FNNNS9 & 41,62 & 0,37 \\
\hline FNNNS10 & 49,75 & 0,45 \\
\hline FNNNS11 & 44,83 & 0,40 \\
\hline FNNNS12 & 45,83 & 0,41 \\
\hline FNNNS13 & 43,33 & 0,38 \\
\hline FNNNS14 & 33,96 & 0,29 \\
\hline FNNNS15 & 0 & 0 \\
\hline
\end{tabular}

Sumber : Pengolahan penelitian, 2013 
Penelitian ini lebih mengutamakan merubah jumlah node dan learning rate dengan alasan seperti pada tulisan Wahyudi (2013) yang menjelaskan bahwa jumlah node berpengaruh pada pengenalan data input yang merupakan faktor pengali terhadap bobot yang akan dilatih dan diteruskan kelapisan tersembunyi untuk kemudian diteruskan kelapisan output. Sedangkan learning rate berpengaruh terhadap proses pelatihan baik waktu maupun kesalahan yang dihasilkan, semakin tinggi laju pembelajaran maka proses pembelajaran semakin cepat, tetapi akan meningkatkan nilai kesalahan juga. Namun ternyata karena ketidakstabilan software Idrisi Selva menyebabkan pernyataan tersebut tidak terbukti dalam penelitian ini, hal tersebut dapat dilihat dari hasil akurasi perhitungan software Idrisi Selva bernilai tinggi, belum tentu overall accuracy yang sesuai keadaan lapangan untuk setiap simulasi jaringan syaraf tiruan bernilai tinggi juga, hal tersebut dapat dilihat pada grafik yang digambarkan pada gambar 9 dan 10 .

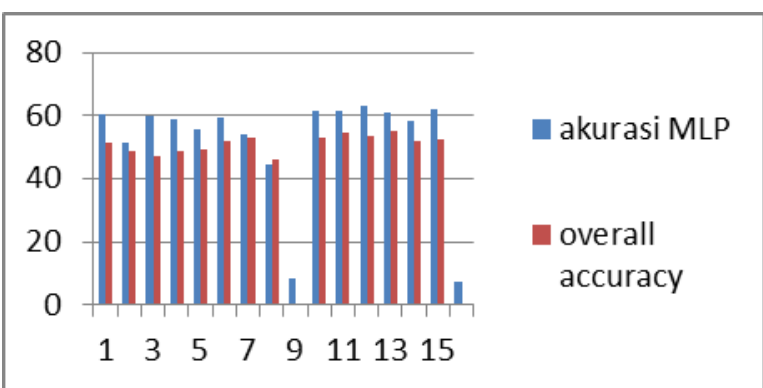

Gambar 9. Fuzzy Neural Network dengan input 4 Band Citra ALOS AVNIR-2 (14 kelas PL)

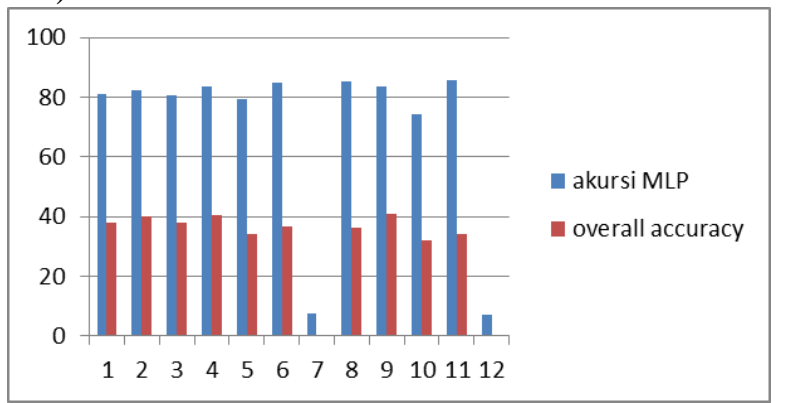

Gambar 10. Fuzzy Neural Network dengan input 4 Band Citra ALOS AVNIR-2 dan data non spektral (14 kelas PL)

Citra hasil klasifikasi dari simulasi yang memiliki akurasi terbaik kemudian dibuat peta penggunaan lahannya dapat dilihat pada gambar 9, 10, dan 11.

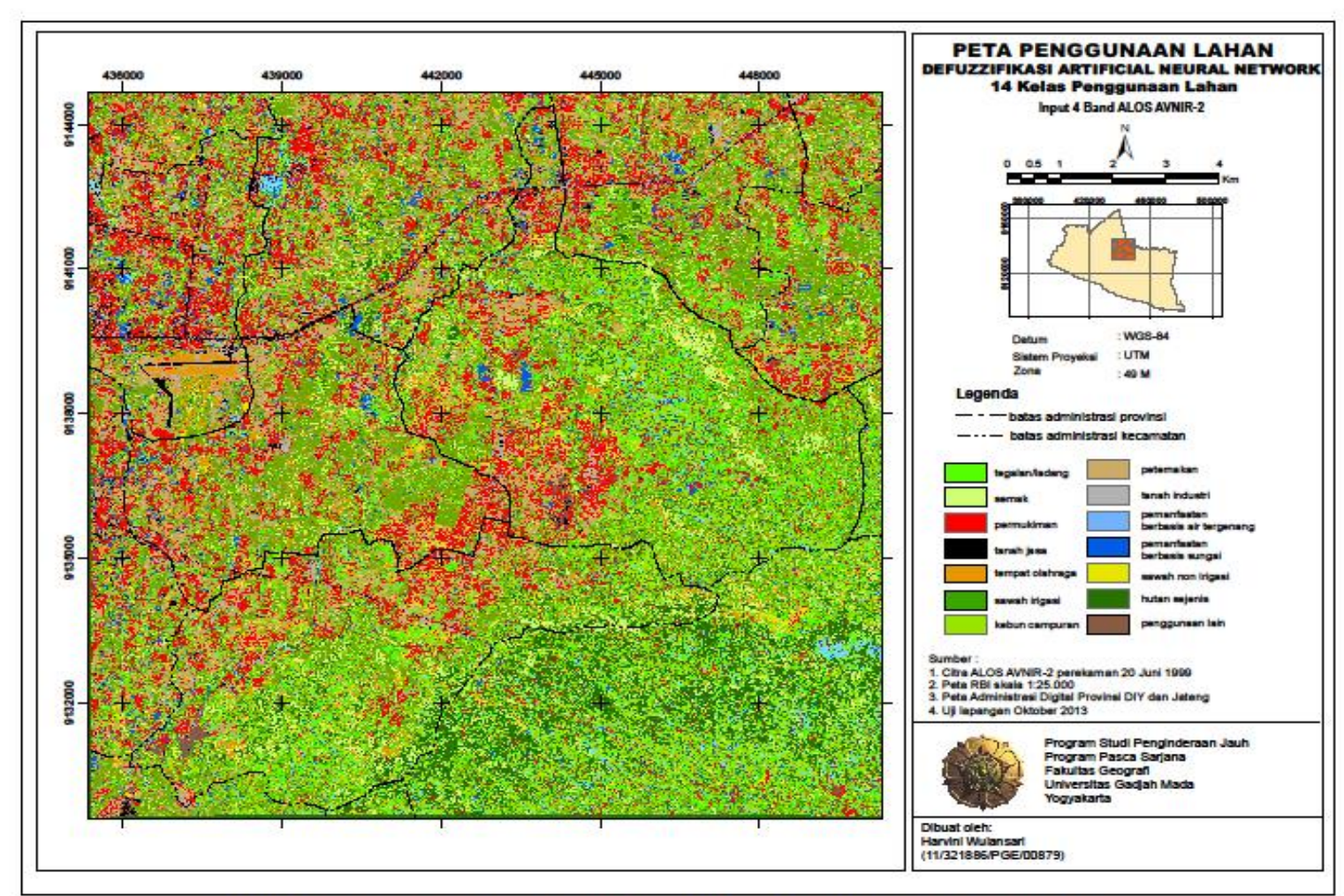

Gambar 9. Peta Penggunaan Lahan Defuzzifikasi Artificial Neural Network Input 4 Band ALOS AVNIR-2 


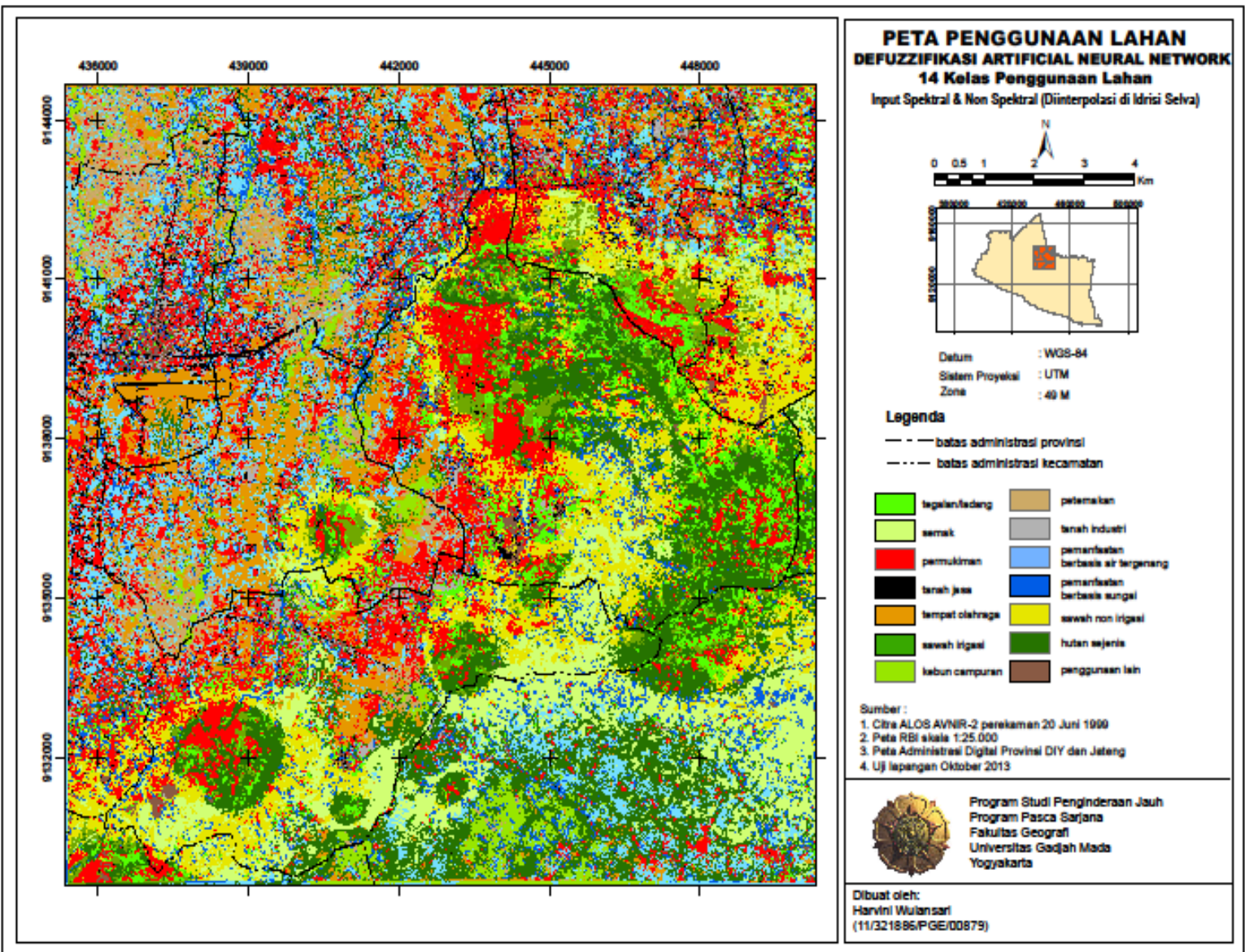

Gambar 10. Peta Penggunaan Lahan Defuzzifikasi Artificial Neural Network Input Spektral dan Non Spektral (diinterpolasi di Idrisi Selva)
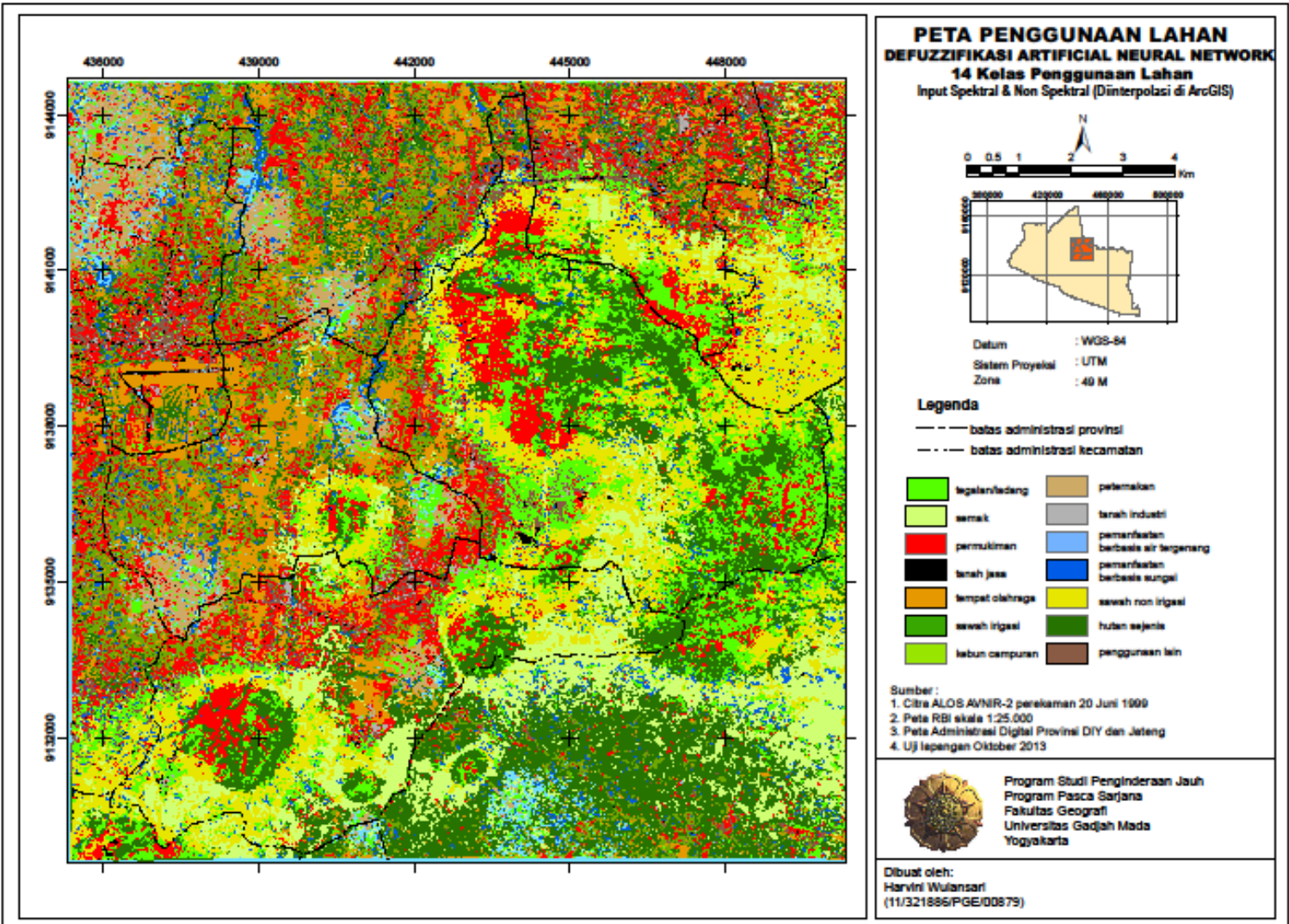

Gambar 11. Peta Penggunaan Lahan Defuzzifikasi Artificial Neural Network Input Spektral dan Non Spektral (diinterpolasi di ArcGIS) 
Tabel 8. Perhitungan akurasi penghasil dan pengguna untuk 14 kelas penggunaan lahan proses defuzzifikasi menggunakan artificial neural network atau jaringan syaraf tiruan (input 4 band )

\begin{tabular}{lllll}
\hline \multirow{2}{*}{ Kelas } & \multicolumn{2}{c}{ Producer's accuracy } & \multicolumn{2}{c}{ User's accuracy } \\
\cline { 2 - 5 } & Akurasi (\%) & $\begin{array}{l}\text { Omisi } \\
\text { kesalahan }(\%)\end{array}$ & Akurasi (\%) & $\begin{array}{l}\text { Komisi } \\
\text { kesalahan }\end{array}$ \\
\hline $\mathrm{Tg}$ & 36,07 & 63,93 & 36,46 & 63,54 \\
$\mathrm{Sm}$ & 55,19 & 44,81 & 74,72 & 25,28 \\
$\mathrm{Pm}$ & 65,42 & 34,58 & 72,35 & 27,65 \\
$\mathrm{Tj}$ & 51,72 & 48,28 & 75,00 & 25,00 \\
$\mathrm{To}$ & 96,72 & 3,28 & 72,84 & 27,16 \\
$\mathrm{Si}$ & 68,09 & 31,91 & 28,15 & 71,85 \\
$\mathrm{Kc}$ & 46,39 & 53,61 & 30,68 & 69,32 \\
$\mathrm{Pt}$ & 23,21 & 76,79 & 9,74 & 90,26 \\
$\mathrm{Ti}$ & 60,00 & 40,00 & 43,94 & 56,06 \\
$\mathrm{At}$ & 43,50 & 56,50 & 56,20 & 43,80 \\
$\mathrm{Sg}$ & 47,08 & 52,92 & 66,48 & 33,52 \\
$\mathrm{Sn}$ & 65,12 & 34,88 & 96,55 & 3,45 \\
$\mathrm{Hs}$ & 61,59 & 38,41 & 80,90 & 19,10 \\
$\mathrm{Pl}$ & 11,54 & 88,46 & 40,91 & 59,09 \\
\hline
\end{tabular}

Sumber : Pengolahan penelitian, 2013

Tabel 9. Perhitungan akurasi penghasil dan pengguna untuk 14 kelas penggunaan lahan proses defuzzifikasi menggunakan artificial neural network atau jaringan syaraf tiruan (input 4 band dan data non spektral) interpolasi data kemiringan lereng dan solum tanah di Idrisi Selva

\begin{tabular}{lllll}
\hline \multirow{2}{*}{ Kelas } & \multicolumn{3}{c}{ Producer's accuracy } & \multicolumn{2}{c}{ User's accuracy } \\
\cline { 2 - 5 } & Akurasi (\%) & $\begin{array}{l}\text { Omisi } \\
\text { kesalahan }(\%)\end{array}$ & Akurasi $(\%)$ & $\begin{array}{l}\text { Komisi } \\
\text { kesalahan }(\%)\end{array}$ \\
\cline { 2 - 5 } $\mathrm{Tg}$ & 6,56 & 93,44 & 5,61 & 94,39 \\
$\mathrm{Sm}$ & 0 & 100 & 0 & 100 \\
$\mathrm{Pm}$ & 73,83 & 26,17 & 50,97 & 49,03 \\
$\mathrm{Tj}$ & 52,41 & 47,59 & 71,03 & 28,97 \\
$\mathrm{To}$ & 98,91 & 1,09 & 65,82 & 34,18 \\
$\mathrm{Si}$ & 0 & 100 & 0 & 100 \\
$\mathrm{Kc}$ & 63,25 & 36,75 & 94,59 & 5,41 \\
$\mathrm{Pt}$ & 0 & 100 & 0 & 100 \\
$\mathrm{Ti}$ & 0 & 100 & 0 & 100 \\
$\mathrm{At}$ & 19,21 & 80,79 & 18,78 & 81,22 \\
$\mathrm{Sg}$ & 82,10 & 17,90 & 57,65 & 42,35 \\
$\mathrm{Sn}$ & 19,07 & 80,93 & 28,47 & 71,53 \\
$\mathrm{Hs}$ & 52,73 & 47,27 & 48,74 & 51,26 \\
$\mathrm{Pl}$ & 8,97 & 91,03 & 20,90 & 79,10 \\
\hline
\end{tabular}


Tabel 10. Perhitungan akurasi penghasil dan pengguna untuk 14 kelas penggunaan lahan proses defuzzifikasi menggunakan artificial neural network atau jaringan syaraf tiruan (input 4 band dan data non spektral) ) interpolasi data kemiringan lereng dan solum tanah di ArcGIS

\begin{tabular}{lllll}
\hline \multirow{2}{*}{ Kelas } & \multicolumn{3}{l}{ Producer's accuracy } & \multicolumn{2}{l}{ User's accuracy } \\
\cline { 2 - 5 } & Akurasi (\%) & $\begin{array}{l}\text { Omisi } \\
\text { kesalahan }(\%)\end{array}$ & Akurasi (\%) & $\begin{array}{l}\text { Komisi } \\
\text { kesalahan }(\%)\end{array}$ \\
\cline { 2 - 4 } tg & 0 & 100 & 0 & 100 \\
$\mathrm{sm}$ & 34,02 & 65,98 & 34,75 & 65,25 \\
$\mathrm{pm}$ & 57,01 & 42,99 & 48,90 & 51,10 \\
$\mathrm{tj}$ & 5,52 & 94,48 & 22,86 & 77,14 \\
$\mathrm{to}$ & 98,36 & 1,64 & 94,74 & 5,26 \\
$\mathrm{si}$ & 59,57 & 40,43 & 42,86 & 57,14 \\
$\mathrm{kc}$ & 86,75 & 13,25 & 54,96 & 45,04 \\
$\mathrm{pt}$ & 15,18 & 84,82 & 4,58 & 95,42 \\
$\mathrm{ti}$ & 2,07 & 97,93 & 33,33 & 66,67 \\
$\mathrm{at}$ & 81,36 & 18,64 & 88,34 & 11,66 \\
$\mathrm{sg}$ & 74,71 & 25,29 & 88,89 & 11,11 \\
$\mathrm{sn}$ & 87,44 & 12,56 & 78,99 & 21,01 \\
$\mathrm{hs}$ & 43,18 & 56,82 & 50,26 & 49,74 \\
$\mathrm{pl}$ & 7,05 & 92,95 & 7,05 & 92,95 \\
\hline
\end{tabular}

Sumber : Pengolahan penelitian, 2013

Tabel 11. Perbandingan overall accuracy dan indeks kappa dengan proses defuzzifikasi menggunakan artificial neural network atau jaringan syaraf tiruan (input 4 band) 14 kelas penggunaan lahan.

\begin{tabular}{lll}
\hline Input Data & overall accuracy & indeks kappa \\
\hline 4 Band ALOS AVNIR-2 & $55 \%$ & 0,51 \\
Kemiringan lereng, solum tanah & $40 \%$ & 0,35 \\
(diolah langsung pada software & & \\
Idrisi Selva) dan tekstur citra & \\
Kemiringan lereng, solum tanah $49,75 \%$ & 0,45 \\
(interpolasi di software ArcGIS & \\
kemudian pengolahan di Idrisi & \\
Selva) dan tekstur citra & \\
\hline
\end{tabular}

Perhitungan producer's accuracy, user's accuracy, overall accuracy dan nilai indeks kappa dapat dilihat pada tabel 8, 9 dan 10.

Penelitian ini menghasilkan overall accuracy dan indeks kappa yang kurang baik atau kurang layak, namun demikian hasilnya masih dapat diterima, menurut Sutanto (2013) acuan akurasi yang dianggap layak untuk penggunaan citra satelit yaitu $80 \%-85 \%$. Ada beberapa kemungkinan diantaranya yaitu perbedaan antara data citra dan kapan dilakukannya penelitian, kemungkinan kondisi lapangan sudah berubah. Selain itu
Sumber : Pengolahan penelitian, 2013

kemungkinan dalam hal penentuan derajat keanggotaan himpunan fuzzy dibutuhkan analisis yang baik oleh orang yang benar benar ahlinya, karena dalam penelitian ini peneliti masih pemula dalam melakukan analisis/bukan ahlinya maka bisa saja terjadi kesalahan dalam pemberian bobot-bobot (membership grade) keanggotaan. Hasil survei lapangan untuk solum tanah yang kurang baik juga bisa menyebabkan hasil akurasi kurang maksimal karena meskipun survei penentuan solum tanah dilakukan langsung dilapangan tetapi setelah dianalisis masih terdapat lokasi-lokasi yang seharusnya 
memiliki solum tanah yang dangkal tetapi hasil surveinya solum tanahnya lebih dalam atau misal pada kemiringan lereng yang curam yang seharusnya lapisan tanahnya tidak begitu dalam tetapi data survei lapangan solum tanahnya dangkal. Metode interpolasi yang digunakan bisa juga menjadi salah satu kemungkinan hasil penelitian ini kurang bagus, karena kurang mewakili kondisi lapangan yang sebenarnya.

\section{SIMPULAN}

Proses penelitian ini keseluruhan berhasil dengan baik, menghasilkan peta yang informatif dengan klasifikasi yang bervariasi, walaupun dari sudut pandang ketelitian menghasilkan overall accuracy dan indeks kappa yang kurang baik atau kurang layak apabila menggunakan acuan akurasi yang dianggap layak untuk penggunaan citra satelit $80 \%-85 \%$, namun demikian hasilnya masih dapat diterima. Pendekatan non parametrik yang dapat memadukan input data spektral dan non spektral yang diharapkan dapat meningkatkan akurasi tidak begitu banyak menambahkan akurasi hanya kurang dari $1 \%$. Hasil perhitungan overall accuracy untuk 14 kelas penggunaan lahan proses defuzzifikasi artificial neural network (jaringan syaraf tiruan) yang melibatkan data spektral saja (4 band ALOS AVNIR-2) sebesar 55\% dan indeks kappa 0,51. Sementara itu ketika data non spektral seperti kemiringan lereng, solum tanah dan tekstur citra dilibatkan sebagai input, akurasinya semakin menurun pada 14 kelas penggunaan lahan, dengan overall accuracy sebesar $40 \%$ dan indeks kappa 0,35 dimana input kemiringan lereng dan solum tanah diinterpolasi pada software ArcGIS terlebih dahulu, sedangkan yang langsung diinterpolasi pada software Idrisi Selva overall accuracy sebesar $49,75 \%$ dan indeks kappa $0.45 \%$.

\section{REKOMENDASI}

Simulasi jaringan syaraf tiruan untuk input data non spektralnya bisa dicoba dengan memasukkan input tambahan yang berbeda, sehingga diharapkan bisa mendapatkan hasil akurasi yang lebih baik. Input tambahan bisa dicoba dengan metode yang lain untuk membandingkan hasil akurasimya.

\section{DAFTAR PUSTAKA}

Danoedoro, P., 2012, Pengantar Penginderaan Jauh Digital, Penerbit Andi, Yogyakarta.

Denaswidhi, E., 2008, Pendekatan Logika Samar (Fuzzy Logic) untuk Pemetaan Penggunaan Lahan Sebagian Kota Semarang dari Citra Landsat ETM+ Multitemporal, Skripsi, Fakultas Geografi Universitas Gadjah Mada Yogyakarta.

Direktorat Pemetaan Tematik, 2012, Norma, Standar, Prosedur dan Kriteria, Deputi Bidang Survei, Pengukuran dan Pemetaan, BPN RI.

Hardjowigeno, S., dan Widiatmaka, 2007, Evaluasi Kesesuaian Lahan dan Perencanaan Tataguna Lahan, Gadjah Mada University Press, Yogyakarta. Jensen, J.R., 2005, Introductory Digital Image Processing : A Remote Sensing Perspective, Third Edition, Pearson Education, Inc., United States of America.

Kristanto, A., 2004, Jaringan Syaraf Tiruan: Konsep Dasar, Algoritma dan Aplikasi, Penerbit Gava Media, Yogyakarta.

Kurniawan, W., 2012, Studi Kemampuan Fuzzy Neural Network Dalam Klasifikasi Perpiksel Penutup Lahan Menggunakan Citra Landsat 7 Etm+, Skripsi, Fakultas Geografi, Universitas Gadjah Mada Yogyakarta.

Kusumadewi, S., 2004, Membangun Jaringan Syaraf Tiruan Menggunakan MATLAB dan EXCEL LINK, Penerbit Graha Ilmu, Yogyakarta.

Novamizanti et.al., 2010, Optimasi Logika Fuzzy Menggunakan Algoritma Genetika Pada Identifikasi Pola Tanda Tangan, Jurnal, Konferensi Nasional Sistem dan Informatika Bali, hal : 153.

Samudra, I., 2007, Kajian Kemampuan Metode Jaringan Syaraf Tiruan untuk Klasifikasi Penutup Lahan dengan Menggunakan Citra ASTER, Tesis, Program Pasca Sarjana Fakultas Geografi Universitas Gadjah Mada Yogyakarta. 
Sutanto, 2013, Metode Penelitian

Penginderaan Jauh, Penerbit Ombak, Yogyakarta.

Wahyudi, D., 2013, Kajian Jaringan Syaraf Tiruan Berbasis Citra ASTER VNIR dan SWIR untuk Klasifikasi Penutup dan Penggunaan Lahan di Kecamatan Katingan Tengah, Kabupaten Katingan, Provinsi Kalimantan Tengah, Tesis,
Program Pasca Sarjana Fakultas

Geografi Universitas Gadjah Mada

Yogyakarta.

Schowengerdt, R.A., 1983, Techniques for

Image Processing and Classification in

Remote Sensing, Academic Press,

London.

Tutorial Idrisi Selva, 2012, Help, Idrisi Selva. 